\title{
EVALUATION OF MUNICIPAL SOLID WASTE MANAGEMENT SYSTEM AND WILLINGNESS-TO-PAY FOR ITS IMPROVEMENTS IN ILORIN, KWARA STATE, NIGERIA
}

\author{
A. M. Ayanshola1,*, A. S. Aremu ${ }^{2}$, S. 0. Jacob ${ }^{3}$, S. 0. Bilewu ${ }^{4}$ and A. W. Salami' ${ }^{5}$ \\ 1, 2, 5 DEPT. OF WATER RESOURCES AND ENVIRONMENTAL ENGR., UNIV. OF ILORIN, ILORIN, KWARA STATE, NiGERIA \\ 3, 4 DePartment of Civil Engineering, University of IloRin, P.M.B. 1515, ILORIN, KWARA STATE, NiGERIA \\ Email addresses: ${ }^{1}$ engramayanshola@gmail.com, ${ }^{2}$ aremu-adeniyi@yahoo.com,3samjay0o7@yahoo.com, \\ 4 bilewuk@yahoo.com,5awsalami2009@gmail.com
}

\begin{abstract}
This paper reports the evaluation of households' usage of the current solid waste management system (SWMS) within the city of Ilorin, central Nigeria and investigates the determinants of household's willingness-to-Pay (WTP) for its improvement Data was collected with the aid of a structured questionnaire administered to households within four neighbourhoods that represent the major subdivisions in the metropolis. The multiple regression model was applied in explaining household's usage of the current system and WTP.The study found that 36\% and 64\% respectively of the households were unsatisfied and moderately satisfied with the current waste management system.The combined effect of household's demographic profiles, geometric profile and position of waste management facility gave a significant fitted model to show the relationship between household's willingness to pay and the considered predictors.
\end{abstract}

Keywords: solid waste, household, waste bin, willingness to pay, municipal

\section{INTRODUCTION}

Solid wastes are unavoidable discards from human activities involving the direct or indirect use of materials provided by nature. Over the years, solid waste generation has steadily increased as a result of global changes associated with population, consumption and industrial development. The world cities generate about 1.3 billion tonnes of solid waste per year and this volume is expected to increase to 2.2 billion tonnes by 2025[1]. Coping with the rapid increase in solid waste generation within urban areas is a challenge to municipal authorities especially in developing countries.The low coverage challenge is attributable to increasing solid waste generation, high management costs, and lack of linkages between stakeholders and stage-wise understanding of the factors that affect solid waste management [2].

Improper solid waste management leads to substantial health, environmental, social, and economic impacts. A study has shown that significant etiologic relationships exist directly or indirectly between numerous human diseases and improperly managed solid wastes [3]. Also, solid waste causes extensive environmental effects in terms of emission of greenhouse gases and carcinogens, climate change, and soil and water pollution. Social effects include blockage of drains, deterioration of the built environment, nuisance, unsightliness, and loss of tourist income. In terms of unquantifiable costs, improperly managed solid wastes usually results in down-stream costs higher than what it would have initially cost to manage the waste properly [1]. Hence municipalities would prefer to concentrate efforts on proper management of generated solid wastes.

Financial sustainability in solid waste management is a major concern for cities all over the world [4]. The total expenditure required for proper solid waste management as a percentage of household income in low-income, middle-income and high-income countries is $0.76-2.6, \quad 0.5-1.3$, and $0.2-0.5 \%$ respectively [5]. The cost of providing solid waste management is exceptionally high in developing 
countries though collection coverage is low. For example, most cities in Africa do not collect the entire generated solid wastes, with collection rates ranging from 20 to $80 \%$ and are limited to high visibility areas, the wealthy, and businesses willing to pay for this service [6]. In Nigeria, solid waste collection cost is relatively high due to the unplanned way in which collection operation is undertaken [7]. If solid waste management is to be improved, waste generators may need to pay more. Similarly for any improvement strategy which shows a pragmatic shift from a free social service (zero price) to a commodity-based (price tagged) service, it is necessary to know the willingness of waste generators to contribute to the cost of such improved service. Invariably 'willingness to pay' creates an impression that the management of solid waste is a commodity rather than a free social service, at least to improve user's satisfaction and defray some capital, labour, operating or maintenance costs associated it.

Recently, several studies have reported willingness-to pay (WTP) for improved solid waste management in some cities across the globe. The results of studies inKuwait municipality [8]; Kampala City, Uganda [9]; Eldoret town in Kenya [10]; Abeokuta, Nigeria [11]; Akuapem North District in Ghana [12]; New Juaben Municipality, Ghana [13]; Islamabad, Pakistan [14] show that households are willing to pay varying amount of money to improve solid waste management. In general households are willing to pay the equivalent of between US\$ 1.85 and US\$ 1.85 per month. These studies have also shown that WTP is influenced by some parameters such as sex of respondent, income, education, age, household size and ownership, safety concerns, walking time to public dumpster, disposal methods, level of satisfaction, and environmental visibility.

However most of these studies tend not to evaluate the existing solid waste management system in order to get the level of satisfaction before evaluating WTP. This study is aimed at the evaluation of households' usage of the current solid waste management system within the city of Ilorin, central Nigeria and investigates the determinants of household's WTP for improved waste management service.

\section{MATERIALS AND METHODS}

\subsection{Study Area}

The ancient city of Ilorin, the capital of Kwara State in Central Nigeria is located on latitude $8^{\circ} 30^{\prime} \mathrm{N}$ and longitude $4^{\circ} 35^{\prime} \mathrm{E}$. It is about 500 kilometres from Abuja, the Federal Capital of Nigeria and strategically located at the geographical and cultural confluence of the Northern and Southern part of Nigeria (Fig. 1). Ilorin metropolis is made up of three local government areas namely Ilorin West, Ilorin East and Ilorin South. The city can be classified into three sub-areas; old residential area, new residential area and government reservation area [15]. The old residential area is the indigenous part of town which is located in the central core area. The new residential area is the post-colonial area located around the core area of the city, while the government reservation area is the high status neighbourhood area. The population of Ilorin was about 777,667 in 2006 [16] and was estimated as 971,248 at the end of 2014. The estimated amount of solid waste generation per day is 476 tons in 2014based on an average per capita generation rate of $0.49 \mathrm{~kg}$ for Nigeria [18].

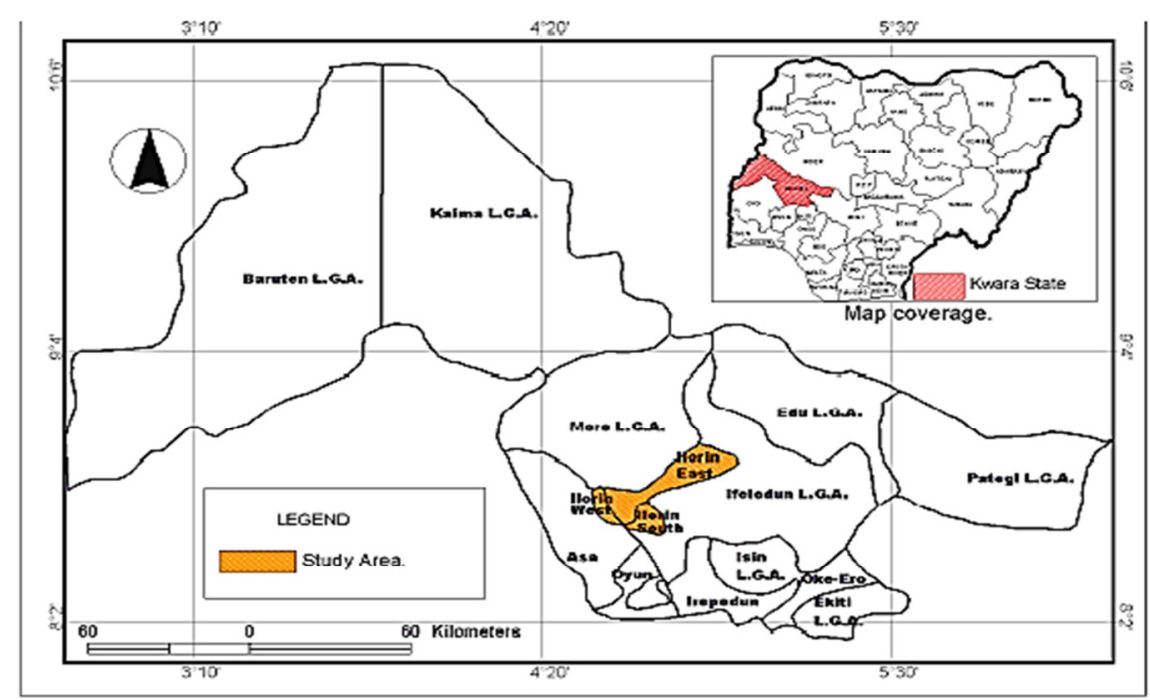

Figure 1: Map of Kwara State showing the study Area [17] 
The two principal agencies responsible for the management of urban solid waste in Ilorin are the Kwara State Environmental Protection Agency (KWEPA) and Kwara State Waste Management Company (KWMC). Presently, KWMC handles the collection and disposal of wastes from municipal solid waste bins (7.54m $\mathrm{m}^{3}$-capacity Roll on - Roll off) [19]. There are a total of 108 of such waste bins within the metropolis and KWMC uses a fleet of medium- duty trucks to haul the waste bins. Solid waste management by KWMC is free-of-charge. In recent times KWMC has been facing many challenges such as coping with the huge amount of solid waste generation, high operation and maintenance costs, accessibility challenges and proper disposal of collected wastes. On the other hand, some residents do experience low levels of satisfaction based on deferring issues related to the service provided by KWMC. This study intends to evaluate the current solid waste management practice so as to address such dissatisfactions and also determine if waste generators are willing to pay for an improved service.

\subsection{Data Collection and Sampling Technique}

Data was collected with the aid of a structured questionnaire which contained open-ended questions. The questionnaire was structured to collect data on: (i) household demographic profile (ii) users' satisfaction and (iii) usage of the current municipal waste bins.

The questionnaire was administered to households within four neighbourhoods that represent the major subdivisions in the metropolis. The stratified neighbourhoods are:

i. Government Reservation Area (GRA)

ii. Housing Estates - Irewolede, Mandate, Kulende, Royal valley, Adewole, Federal Housing Estate Oloje and Idiagbon Estate

iii. Modern Layouts - Agaba-dam area, Tanke junction, and airport area and;

iv. Traditional Layout - Oja-Oba, Sabo-line, Ipata, Akerebiata, Oloje, Tanke-bubu, Tanke-Iledu, and Taiwo-Isale.

Six hundred questionnaires were administered to selected households within each neighbourhood. A total of 598 was retrieved out of which 584 was useable for analyses.

\subsection{Data Analysis and Modelling}

Households' WTP is affected by several factors which are evaluated as follows:

(i) WTP as the dependent variable was analysed with respect to household demographic profile: that is, educational status of the household head (EDH), average income of household head (AIH), household population (HPO) and household category (HHC), all of which are the independent variables.

(ii) WTP as the dependent variable was evaluated with respect to users' satisfaction: i.e. awareness about municipal waste bin (AWB), usage of municipal waste bin (UMB), and proximity of municipal waste bin (PMB).

(iii) Usage of the current municipal waste bin as the dependent variable is evaluated with respect to independent variables such as household storage bin (HSB), awareness about municipal waste bin (AWB), proximity of municipal waste bin (PMB), availability of municipal waste bin (AVB) and average income of the household (AIH).

In order to establish the structural relationship between the variables and household's willingness to pay and to reveal the possible determinants of household WTP, multivariate statistical analysis was performed. The multiple regression model [20] is given as:

$Q=f\left(X_{1}, X_{2}, X_{3} \ldots X_{n}\right)+E$

$Q=A_{0}+A_{1} X_{1}+A_{2} X_{2}+\ldots A_{n} X_{n}+E$

Where $\mathrm{Q}$ is the dependent variable, $f(X)$ denotes the function of explanatory independent variables $X_{1}, X_{2}$, $X_{3} \ldots X_{n}$ and $E$ is the standard error.

The results obtained are interpreted based on the following hypotheses:

Hypothesis 1: $\mathrm{H}_{0}: \beta_{\mathrm{i}}=0$ (The regression coefficient is not significant); $\mathrm{H}_{1}: \beta_{\mathrm{i}} \neq 0$ (The regression coefficient is significant)

Decision rule: Reject $\mathrm{H}_{0}$ (null-hypothesis) if $P$-value $\leq \alpha$ (level of significance $=0.05$ ).

Hypothesis 2: $\mathrm{H}_{0}$ : the fitted model is not significant; $\mathrm{H}_{1}$ : the fitted model is significant

Decision rule: Reject $\mathrm{H}_{0}$ (null-hypothesis) if $P$-value $\leq \alpha$ (level of significance $=0.05$ ) .

The coefficient of regression with the $p$-values explains the significance of the independent variables with the dependent while the $\beta$-values states the contribution made by the individual independent variables to the model. The correlation coefficient shows the adequacy of the independent variables in 
explaining the WTP while the probability value for the F-test statistic determines the adequacy or significance of the fitted model. A statistical package was used for regression analysis and to test for significant differences between WTP and household demographic profile; WTP and users' satisfaction; and usage of municipal waste bins and household demographic profile/users' satisfaction.

\section{RESULTS AND DISCUSSION}

\subsection{Demographic Profile of the Studied Households}

The socio-economic characteristics of respondents and house demographics are presented in Table 1. A total of $52 \%$ of the respondents were males while $48 \%$ were females. Household population varies from 1 to10 with an average of 6 people per household. Households with 5 and 6 persons have the highest percentage while households with 2 persons are the least prominent. About $41 \%$ of the total sampled household heads has post-graduate degree qualifications, $20 \%$ has only first degree, $15 \%$ has School Leaving Certificate while $5 \%$ are uneducated. In terms of income, $64 \%$ of the total population of household heads earns above 100,000 while $36 \%$ earns below $\$ 100,000$ per annum. Bungalow is the most dominant category of house type $(54 \%)$ and multi-tenant (face-to-face) is the lowest (7\%).

\subsection{Peoples' Perception on the Existing Solid Waste Management System}

Peoples' perception on the current municipal solid waste management system in some parts of the city is presented in Table 2. A total of $93 \%$ of the respondents use the municipal waste bins though the frequency of usage per week varies considerably. Also $48 \%$ of the respondents have the waste bins situated within $200 \mathrm{~m}$ reach of their residence. The observed environmental problems at collection points include litter, odour and eyesore (unsightly conditions).

Table 1: Socio-economic characteristics of respondents and house demographics

\begin{tabular}{|c|c|c|c|c|c|c|c|c|c|}
\hline \multicolumn{2}{|l|}{ Gender } & \multicolumn{2}{|c|}{ Income of Household } & \multicolumn{2}{|l|}{ Education Status } & \multicolumn{2}{|l|}{ House Type } & \multicolumn{2}{|c|}{ Household Size } \\
\hline Male & 52 & Below $\$ 100,000$ & 36 & No formal education & 20 & Multi-Tenant & 7 & $1-5$ & 44 \\
\hline Female & 48 & $\geq ® 100,000$ & 64 & Primary School & 41 & Blocks of Flats & 24 & $6-10$ & 56 \\
\hline & & & & Secondary School & 15 & Story Building & 15 & Above 10 & 0 \\
\hline & & & & Graduate & 19 & Bungalow & 54 & & \\
\hline & & & & Postgraduate & 5 & & & & \\
\hline
\end{tabular}

Table 2: Peoples' perception on existing solid waste management system

\begin{tabular}{|c|c|c|c|c|}
\hline \multirow[b]{2}{*}{ Variables } & \multicolumn{4}{|c|}{ Neighbourhoods } \\
\hline & GRA (\%) & $\begin{array}{l}\text { Traditional } \\
\text { Layout (\%) }\end{array}$ & $\begin{array}{l}\text { Modern } \\
\text { Layout (\%) }\end{array}$ & $\begin{array}{l}\text { Housing } \\
\text { Estate (\%) }\end{array}$ \\
\hline \multicolumn{5}{|c|}{$\begin{array}{l}\text { Observed Environmental } \\
\text { Problems }\end{array}$} \\
\hline Litter & 3 & 6 & 14 & 4 \\
\hline Odour/smoke & 6 & 13 & 28 & 9 \\
\hline Eyesore & 6 & 2 & 2 & 7 \\
\hline \multicolumn{5}{|c|}{ Municipal Waste Bin Usage } \\
\hline Yes & 15 & 30 & 30 & 18 \\
\hline No & 0 & 4 & 2 & 1 \\
\hline \multicolumn{5}{|c|}{$\begin{array}{l}\text { Frequency of Waste Bin Usage } \\
\text { (per week) }\end{array}$} \\
\hline 5 times & 0 & 4 & 0 & 0 \\
\hline 4 times & 8 & 2 & 5 & 4 \\
\hline 3 times & 2 & 12 & 8 & 8 \\
\hline Irregular & 4 & 19 & 12 & 12 \\
\hline \multicolumn{5}{|c|}{ Proximity of Municipal Waste } \\
\hline$<=200 \mathrm{~m}$ & 3 & 19 & 16 & 10 \\
\hline$>200 \mathrm{~m}$ & 12 & 14 & 16 & 10 \\
\hline \multicolumn{5}{|c|}{ Level of Satisfaction } \\
\hline Satisfactory & 0 & 1 & 1 & 0 \\
\hline Moderate & 10 & 19 & 17 & 19 \\
\hline Unsatisfactory & 5 & 13 & 14 & 1 \\
\hline
\end{tabular}


In terms of satisfaction with the current solid waste management system, only $2 \%$ of the respondents consider the system satisfactory while $65 \%$ are moderately satisfied. Hence, the level of satisfaction of the current solid waste management system in Ilorin metropolis is very low.

\subsection{WTP for Improved Solid Waste Management Services}

Since the level of satisfaction is low, WTP for improved service was evaluated with respect to household's demographic profile. About $65 \%$ of the sampled population were willing to participate in improving the solid waste management of their neighbourhood while $69 \%$ are willing to pay for improved services. Further analysis was carried out to determine the predictors of household's willingness to pay (WTP). From Table 3, HPO has a negative $\alpha$-value (coefficient) which means that the predictor is negatively related to household's WTP for improved SWMS while EDH, AIH, and HHC have positive relationship with WTP. This is in consonant with study conducted in Islamabad, Pakistan [14] and Kampala, Uganda $[9,21]$ in which similar variables have positive effects on WTP for improvement on solid waste management services. The predictor AIH has the strongest unique contribution to explain the dependent variable because its $p$-value is the highest (0.448) while the least contribution is made by HPO ( $p$-value is 0.096).

For all the predictors in Table 3 , the p-values are greater than the level of significance (0.05), therefore, the $\mathrm{H}_{0}$ (null-hypothesis) is not rejected. The value of $\mathrm{R}$-squared is 0.081 , suggesting that about $8.1 \%$ of the variation in the household's WTP is explained by the model while the remaining $91.9 \%$ is due to the random effect of the data. The probability value for the F-test statistic $(0.08)$ is greater than level of significance (0.05), therefore, the hypothesis 2 (nullhypothesis) is not rejected. The fitted model, though not significant, is as given in equation 3 and it shows the relationship between the WTP and demographic profile of the study area.

$$
\begin{gathered}
W T P=0.1442 E D H+0.0015 A I H-0.0335 H P O \\
+0.0573 H H C+1.0560
\end{gathered}
$$

An evaluation of WTP for improved solid waste management services with respect to the geometric profile and position of SWM facilities is presented in Table 4. It was observed that AWB, UMB and PMB has negative $\alpha$-value (coefficient). This means that the predictors have a negative relation with Household's willingness to pay for improved SWMS. The largest $\beta$ value is -0.0093 which is for average usage of municipal waste bin (UMB). This shows that this predictor make the strongest unique contribution to explaining the dependent variable when the variance explained by all other variables in the model is accounted for. The $\beta$-value for AWB was -0.1494 which is an indication of the least contribution.

The p-values (0.26) for UMB, AWB, and PMB, p-values (0.26) is greater than level of significance (0.05), hence, the $\mathrm{H}_{0}$ (null-hypothesis) is not rejected. The coefficient of determination shows that $4 \%$ of the variation in the Household's Willingness to Pay is explained by the model while the remaining $96 \%$ is due to the random effect of the data.

Table 3: Table of coefficients for predictors of WTP

\begin{tabular}{llllll}
\hline Model & $\alpha$ (coefficient) & Std. Error & $\beta$ & t-value & Sig. (p-value) \\
\hline EDH & 0.1442 & 0.7507 & 0.1947 & 1.92 & 0.058 \\
AIH & 0.0015 & 0.0020 & 0.0806 & 0.76 & 0.448 \\
HPO & -0.0335 & 0.0199 & -0.1667 & -1.68 & 0.096 \\
HHC & 0.0573 & 0.4005 & 0.1489 & 1.43 & 0.156 \\
Constant & 1.0560 & 0.2604 & - & 4.07 & 0.0000 \\
\hline \multicolumn{5}{r}{} & $R$-Squared = 0.0814; Adjusted R-Square = 0.08; Prob. $>$ F=0.0427; Significant at 5\% level
\end{tabular}

Table 4: Table of coefficients for predictors of WTP

\begin{tabular}{llllll}
\hline Model & $\alpha$ (coefficient) & Std. Error & B & t-value & Sig. (p-value) \\
\hline AWB & 0.2909 & 0.2062 & -0.1494 & -1.41 & 0.162 \\
UMB & -0.0089 & 0.1147 & -0.0093 & -0.08 & 0.938 \\
PMB & -0.0989 & 0.1060 & -0.1068 & -0.93 & 0.353 \\
Constant & 1.7808 & 0.2387 & - & 7.46 & 0.000 \\
\hline
\end{tabular}

$R$-Square $=0.04 ;$ Adjusted $R$-Square $=0.0108 ;$ Prob. $>F=0.26$; Significant at $5 \%$ level 
Table 5: Table of coefficients for predictors of WTP

\begin{tabular}{llllll}
\hline Model & $\alpha$ (coefficient) & Std. Error & $\beta$ & t-value & Sig. (p-value) \\
\hline EDH & 0.1642 & 0.0757 & 0.2217 & 2.17 & 0.033 \\
AIH & 0.0042 & 0.0024 & 0.2294 & 1.73 & 0.086 \\
HPO & -0.0286 & 0.0214 & -0.1424 & -1.34 & 0.184 \\
HHC & 0.0556 & 0.0395 & 0.1445 & 1.41 & 0.163 \\
AWB & -0.3460 & 0.2004 & -0.1777 & -1.73 & 0.088 \\
UMB & -0.0382 & 0.1127 & -0.0399 & -0.34 & 0.735 \\
PMB & -0.1430 & 0.1078 & -0.1545 & -1.33 & 0.188 \\
Constant & 1.6834 & 0.3650 & - & 4.61 & 0.000 \\
\hline
\end{tabular}

$R$-square $=0.1883 ;$ Adjusted $R$-square $=0.1170 ;$ Prob $.>F=0.0120 ;$ Significant at $5 \%$ level

The probability value for F-test statistic $(0.026)$ is greater than the level of significance (0.05), thus, the hypothesis 2 (null-hypothesis) is not rejected. The fitted model though not significant is represented by equation 4 .

$$
\begin{gathered}
W T P=-0.2909 A W B-0.0089 U M B \\
-0.0989 P M B+1.7808
\end{gathered}
$$

\subsection{WTP with respect to household demographic,} geometric profile and position of SWM facilities

Table 5 shows that the predictors of WTP. HPO, AIH, AWB, UMB and PMB have a combined negative $\alpha$ value (coefficient). This means that the predictor has a negative relation with Household's willingness to pay for improved SWMS. Also the independent variables $\mathrm{EDH}, \mathrm{AIH}$, and HHC have positive $\alpha$-value (coefficient) which means that the predictors have a positive relationship with Household's willingness to pay for improved SWMS which is similar to the work conducted in Kampala, Uganda [21]. The predictor, AIH as in the case of the study in Kampala city, Uganda [8] and Mekelle city, Ethiopia [22], which has the highest $\beta$-value of 0.2294 made strongest unique contribution to the model. This explained the dependent variable when the variance explained by all other variables in the model is accounted for. The AMB with $\beta$-value of -0.177 made the least contribution to the model.

From Table 5, the P-value (0.0120) is less than the level of significance (0.05). The $\mathrm{H}_{0}$ (null-hypothesis) is thus rejected. The coefficient of determination shows that $18.8 \%$ of the variation in the Household's Willingness to Pay is explained by the model while the remaining $81.2 \%$ is due to the random effect of the data. The probability value for F-test statistic $(0.0120)$ is less than the level of significance (0.05) and the hypothesis 2 (null-hypothesis) is therefore rejected. The significant fitted model and the regression equation that shows the relationship between the WTP and the considered variables is presented in equation 5 .

$$
\begin{array}{rl}
W T P=0.1642 & E D H+0.0042 A I H-0.0286 H P O \\
& +0.0556 H H C-0.3460 A W B \\
& -0,0382 U M E-0.1430 P W B \\
& +1.6834
\end{array}
$$

\section{CONCLUSION}

Assessment of the current usage of the Municipal waste bin (UMB) shows that $60 \%$ of the sampled households use the municipal waste bin and the multivariate regression analysis reveals that proximity (PMB) and visibility (AWB) are significant contributor to the household's usage of municipal waste bin. The fitted model derived from the predictors of URB was significant in explaining the dependent variable. The non-usage of the municipal waste bin by the households is majorly due to unavailability of the facility in such areas, proximity and inadequate collection services. From the results and analysis, it was gleaned that for an improved and efficient system of solid waste management in Ilorin metropolis, $52 \%$ of the total sampled households suggested the provision of more municipal waste bins, public enlightenment and fines for offenders. The combined effect of household's demographic profiles, geometric profile and position of waste management facility (municipal waste bin) gave a significant fitted model for the prediction of household's willingness to pay. The fitted model for usage of municipal waste bin (UMB) and Willingness to pay (WTP) are both significant and thus can be used to predict people's willingness to pay with respect to their usage of the municipal waste bin. 


\section{REFERENCES}

[1] Breeze, R. "Municipal Solid Waste management in Dar Es Salam”, Draft Baseline Analysis, The World Bank, Washington, DC, 23 pp, 2012.

[2] Guerrero, L.A., Maas, G. and Hogland, W. "Solid waste management challenges for cities in developing countries", Waste Management, Vol. 33, pp 220-232, 2013.

[3] Hanks, T.G. "Solid Wastes/Diseases Relationships, A Literature Survey", U.S. Department of Health, Education, and Welfare, Publication No. Pub-999UIH-6, sw-1c, Cincinnati, Ohio, USA, 1967.

[4] UN-Habitat. "Solid Waste Management in the World's Cities, Water and Sanitation in the World's Cities 2010", Earths can Ltd, for and on behalf of United Nations Human Settlements Programme, London/Washington DC, 2010.

[5] Cointreau, S. "Occupational and Environmental Health Issues of Solid Waste Management, Special Emphasis on Middle and Lower Income Countries", Urban Papers, UP-2, The World Bank Group, Washington, D.C., U.S.A, 2006.

[6] Asian Development Bank. "Solid Waste Management in Nepal: Current Status and Policy Recommendations", Publication Stock No. RPT 135789, 69 pp, 2013

[7] Aremu, A. S. In-town tour optimization of conventional mode of municipal solid waste collection, Nigerian Journal of Technology, Vol. 32, No. 3, pp. 443-449, 2013.

[8] Koushki, P., Alhumoud, J.M., and Alduaij, U. "Municipal solid waste in Kuwait: Trends and attitudes on collection, separation and willingness to pay", Kuwait Journal of Science and Engineering, Vol. 31, Number. 2, pp 173-188, 2004

[9] Banga, M., Lokina, R., Mkenda, A. and Kulindwa, K. "Households' Willingness to Pay for Improved Solid Waste Collection Services in Kampala City, Uganda", Department of Economics Working Paper, Series No. 07/11, University of Dar es Salaam, Tanzania, 2011.

[10] Joel, S., Mark, K. and Cheserek G.J. "Economic Valuation of Improved Solid Waste Management in Eldoret Municipality", Journal of Emerging Trends in Economics and Management Sciences (JETEMS) Vol. 3, Number. 6, pp 962-970, 2012.

[11] Achi, H. A., Adeofun, C. O. , Ufoegbune, G.C. , Gbadebo, A.M. and Oyedepo, J. A. “Disposal Sites and Transport Route Selection Using Geographic Information System and Remote Sensing in Abeokuta, Nigeria", Global Journal of Human Social Science Geography \&
Environmental Geosciences, Vol. 12, Issue12, pp 1524,2012

[12] Amfo-Out, R., Waife, E. D., Kwakwa, P. A., and Akpah-Yeboah, S. "Willingness to pay for solid waste collection in semi-rural Ghana: A Logit estimation", International Journal of Multidisciplinary Research, Vol.2, Issue 7, pp 40-49, 2012

[13] Alhassan, M. and Mohammed, J. "Households' Demand for Better Solid Waste Disposal Services: Case Study of Four Communities in the New Juaben Municipality", Ghana. Journal of Sustainable Development, Vol. 6, Number 11, pp 16-25, 2013

[14] Anjum, R. "Willingness to pay for solid waste management services: A case study of Islamabad", CEECC Working Paper, No. 3, Pakistan Institute of Development Economics, Islamabad, 2013.

[15] Ajadi, B.S. and Tunde, A.M. "Spatial Variation in Solid Waste Composition and Management in Ilorin Metropolis, Nigeria", Journal of Human Ecology, Vol. 32, Number 2, pp 101-108, 1996.

[16] Federal Republic of Nigeria. "Official Gazette”, Vol. 94, Number 24, pp B179-B180, 2007.

[17] Adebimpe, R.U. "Climate changes related disasters and vulnerability: an appraisal of the Nigerian policy environment", Environmental Research Journal, Vol. 5, Number 3, pp 97-103, 2011.

[18] Solomon, U. "The State of Solid Waste Management in Nigeria", Waste Management, Vol. 29, pp 27872790, 2009.

[19] Ogwueleka, T. C. and Agunwamba, J. C., Scheduling of solid waste collection routes, Nigerian Journal of TechnologyVol. 28, No. 1, pp. 79 - 92, 2009.

[18] Ayanshola, A.M., Sule, B.F. and Salami, A.W. "Evaluation of Willingness to Pay for Reliable and Sustainable household Water Use in Ilorin, Nigeria", Ethiopian Journal of Environmental Studies and Management, Vol. 6, Number 6, pp 754-762, 2013.

[19] Ojok, O.J., Koech, M.K., Tole, M. and Okot-Okumu, J. "Households' Willingness to Pay for Improved Municipal Solid Waste Management Services in Kampala, Uganda", Science Journal of Environmental Engineering Research, Vol. 2013, Article ID sjeer143, 8 Pages, 2012. doi: 10.7237/sjeer/143

[20] Hagos, D., Mekonnen, M. and Gebreegziaber, Z. 'Households' Willingness to Pay for Improved Urban Waste management in Mekelle City, Ethiopia, Environment for Development, Discussion Paper Series EFD DP 12-06, 2012. 